\title{
Faktor-Faktor Yang Mempengaruhi Audit Delay (Studi Empiris pada Perusahaan LQ45 yang Terdaftar di Bursa Efek Indonesia (BEI) Tahun 2017-2019)
}

\author{
Shafira Nadyne Pradiva ${ }^{1}$, Suyatmin Waskito $\mathrm{Adi}^{2}$ \\ Faculty of Business Economics Muhammadiyah Surakarta University \\ b200191144@student.ums.ac.id
}

\begin{abstract}
Abstrak: Audit delay merupakan permasalahan penting karena mempengaruhi ketepatan waktu penyampaian informasi akuntansi yang digunakan oleh pengguna internal dan eksternal untuk mengambil keputusan. Penelitian ini bertujuan untuk mengetahui faktor-faktor yang mempengaruhi audit delay pada perusahaan LQ45 yang terdaftar di Bursa Efek Indonesia periode 2017-2019. Faktor-faktor tersebut antara lain adalah ukuran perusahaan, profitabilitas, solvabilitas, kompleksitas operasi perusahaan dan opini auditor. Penelitian ini menggunakan metode purposive sampling. Sampel diperoleh dari 28 perusahaan LQ45 selama tiga tahun berturut-turut, sehingga mendapatkan 84 sampel. Instrumen dalam penelitian ini adalah dokumentasi yang berupa laporan keuangan tahunan perushaan yang dipublikasikan oleh BEI. Hasil penelitian ini menunjukkan bahwa rata-rata audit delay 62,85 hari dengan standar deviasi 24,162. Nilai adjusted $R^{2}$ sebesar $36,5 \%$ yang berarti bahwa ukuran perusahaan, profitabilitas, solvabilitas, kompleksitas operasi perusahaan dan opini auditor mampu menjelaskan variabel audit delay sebesar $36,5 \%$ Ukuran perusahaan, profitabilitas dan solvabilitas berpengaruh signifikan terhadap audit delay. Di sisi lain, kompleksitas operasi perusahaan dan opini auditor tidak berpengaruh signifikan terhadap audit delay.

Kata kunci: Audit Delay, kompleksitas, LQ45, opini auditor, profitabilitas, solvabilitas, ukuran perusahaan.
\end{abstract}

Laporan keuangan adalah bentuk pertanggungjawaban pengelolaan keuangan perusahan selama satu periode yang mendukung keberlangsungan suatu perusahaan, terutama bagi perusahaan yang telah go public. Dimana laporan keuangan menjadi sumber informasi penting bagi para investor yang akan menanamkan modalnya di pasar modal. Di Indonesia, perusahaan yang aktif dalam bursa saham dalam memperdagangkan sahamnya di Bursa Efek Indonesia (BEI) wajib melaporkan dan mempublikasikan laporan keuangan kepada Badan Pengawas Pasar Modal dan Lembaga Keuangan (Bapepam-LK) selaku regulator dalam pasar modal Indonesia. Laporan keuangan disusun sesuai Standar Akuntansi Keuangan (SAK) yang berlaku dan diaudit oleh akuntan publik atau auditor independen yang terdaftar di Badan Pengawas Pasar Modal (Bapepam).

Laporan keuangan dikatakan tepat waktu apabila laporan tersebut menyediakan informasi kepada pengambil keputusan sebelum informasi tersebut kehilangan kapasitas untuk mempengaruhi keputusan (Kieso et al, 2014). Ketepatan waktu dalam mempublikasikan laporan keuangan bergantung pada ketepatan auditor dalam menyelesaikan pekerjaannya, karena laporan keuangan tidak dapat dikeluarkan sampai audit menyimpulkan. Menurut Johnson (1998) periode waktu dari akhir tahun fiskal dengan tanggal laporan audit disebut dengan audit delay. 
Pasar modal mengatur perusahaan yang terdaftar dalam pasar modal wajib menyampaikan laporan keuangan secara berkala kepada Badan Pengawas Pasar Modal (Bapepam) dan mengumumkan laporan tersebut kepada masyarakat. Hal ini telah diatur dalam Undang-Undang No. 8 Tahun 1995 tentang Pasar Modal. Pada 26 Juli 2011, Badan Pengawas Pasar Modal dan Lembaga Keuangan (Bapepam LK) mengeluarkan peraturan Bapepam No. X.K.2, Lampiran Keputusan Ketua Bapepam dan LK Nomor Kep-346/BL/2011 tentang Penyampaian Laporan Keuangan Berkala Emiten atau Perusahaan Publik. Pada peraturan tersebut tertulis bahwa setiap perusahaan go public yang terdaftar di Pasar Modal harus laporan keuangan tahunan yang disampaikan kepada Bapepam dan LK yang akan diumumkan kepada masyarakat paling lambat akhir bulan ketiga setelah tanggal laporan keuangan tahunan.

Jika perusahaan tidak mematuhi peraturan tersebut maka akan dikenakan sanksi administratif yang telah ditetapkan oleh Bapepam. Sesuai dengan Keputusan Direksi PT. Bursa Efek Indonesia Nomor: Kep00085/BEI/10-2011 tentang Peraturan Nomor III-F tentang Sanksi. Bagi perusahaan tercatat yang terlambat dalam penyampaian laporan keuangan, terdapat bentuk sanksi yang dikenakan sanksi denda setinggitingginya $\mathrm{Rp}$ 500.000.000,00 (lima ratur juta rupiah).

Demi menghindari sanksi administratif tersebut, perusahaan berupaya menyampaikan laporan tahunan kurang dari batas waktu yang telah diberikan oleh Bapepam-LK. Namun pada kenyataannya masih banyak perusahaan yang terlambat dalam menyampaikan laporan tahunannya. Seperti yang diungkapkan oleh catatan Bursa Efek Indonesia hingga 2019 terdapat 16 emiten yang terlambat dalam menyampaikan laporan keuangan semester I-2019. Padahal BEI telah memberikan waktu kepada perusahaan untuk menyampaikan laporan keuangan semester I2019 yang tidak diaudit dan tidak ditelaah terbatas oleh akuntan publik hingga 31 Juli 2019 dan untuk laporan keuangan yang telah ditelaah terbatas atau diaudit diberikan waktu hingga 2 September 2019 dan 30 September 2019.

Audit delay adalah jarak waktu penyelesaian audit laporan keuangan tahunan. Audit delay dapat diukur berdasarkan jarak waktu antara tanggal penutupan buku 31 Desember sampai dengan tanggal laporan auditor independen yang tercatat pada laporan keuangan (Lestari \& Nuryatno, 2018). Laporan keuangan menggambarkan pencaian kinerja dan prospek masa depan perusahaan. Maka dari itu, keakuratan dan ketepatan waktu penyerahan laporan keuangan adalah hal yang penting dilakukan. Kerjasama antara manajemen perusahaan dengan pihak auditor juga diperlukan karena dapat memenuhi target waktu penyampaian laporan keuangan yang akan berdampak terhadap reaksi pasar dan investor di pasar modal apabila terjadi keterlambatan penyajian laporan keuangan.

Selain alasan diatas, penelitian terdahulu dan data dilapangan menunjukkan adanya ketidakkonsistenan. Hasil penelitian terdahulu yang 
tidak konsisten dapat dilihat pada penelitian Yuliyanti (2011), Widosari (2012), Sari (2015), Apriliane (2015), Apriyana (2017), Abadi (2017) dan Gani (2019). Oleh karena itu, perlu dilakukan penelitian kembali mengenai faktor-faktor yang dapat mempengaruhi audit delay. penelitian ini bertujuan untuk mengidentifikasi pengaruh ukuran perusahaan, profitabilitas, solvabilitas, kompleksitas operasi perusahaan dan opini auditor terhadap audit delay. Data yang digunakan adalah Laporan Keuangan perusahaan yang tergolong LQ 45 pada Bursa Efek Indonesia periode tahun 2017 sampai dengan 2019.

\section{METODE PENELITIAN}

Populasi yang digunakan dalam penelitian ini adalah perusahaan yang tergolong LQ45 di Bursa Efek Indonesia pada tahun 2017 sampai dengan 2019. Metode penentuan sampel dalam penelitian ini adalah menggunakan purposive sampling yaitu metode pemilihan sampel secara tidak acak serta berdasarkan pada pertimbangan dan kriteria yang telah ditentukan.

Kriteria sampel pada penelitian ini antara lain: pertama, perusahaan yang terdaftar dalam indeks LQ45 selama tiga tahun berturut-turut tahun 2017-2019. Kedua, Perusahaan LQ45 yang menggunakan mata uang Rupiah dalam laporan keuangannya. Ketiga, Perusahaan LQ45 tersebut telah menyampaikan laporan keuangan tahunan berturut-turut untuk tahun 2017-2019 yang berisi data dan informasi yang dapat digunakan dalam penelitian ini, serta laporan keuangan tersebut telah diaudit dan disertai laporan auditor independen.

Jenis data dalam penelitian ini adalah kuantitatif, yaitu sumber data yang berbentuk angka. Data yang dianalisis merupakan data sekunder yang bersumber dari dokumentasi perusahaan yaitu laporan keuangan tahunan dari perusahaan yang tergolong LQ45 di Bursa Efek Indonesia (BEI) periode tahun 2017 sampai dengan 2019. Laporan keuangan tersebut telah diaudit dan memperoleh opini dari akuntan publik yang terdaftar di Bapepam-LK.

\section{Variabel penelitian dan pengukurannya}

1. Audit Delay

Audit delay merupakan rentang atau lamanya waktu penyelesaian audit yang diukur dari tanggal penutupan tahun buku sampai dengan tanggal diterbitkannya laporan audit. Audit delay diukur berdasarkan jumlah hari yang diperlukan auditor dalam menyelesaikan proses audit atas laporan keuangan perusahaan yang terhitung sejak tanggal penutupan tahun buku yakni 31 Desember sampai tanggal yang tertera dalam laporan auditor independen.

2. Ukuran Perusahaan

Ukuran perusahaan adalah suatu skala yang dapat digunakan untuk mengklasifikasikan besar atau kecilnya perusahaan berbagai cara dinyatakan dengan total aktiva, nilai pasar saham, dll. Ukuran perusahaan diukur menggunakan total 
aset yang dimiliki oleh perusahaan. Ukuran perusahaan diukur menggunakan log lize (natural logaritma) untuk menghaluskan besarnya angka dan menyamarkan ukuran regresi.

3. Profitabilitas

Profitabilitas perusahaan adalah kemampuan perusahaan untuk memperoleh laba. Profitabilitas dalam penelitian ini diukur menggunakan rasio return on assets (ROA) yang dihitung berdasarkan laba bersih dibagi dengan total aktiva.

4. Solvabilitas

Solvabilitas perusahaan adalah kemampuan untuk memenuhi seluruh kewajiban finansial pada saat perusahaan tersebut dilikuidasi. Dalam penelitian ini solvabilitas diukur menggunakan total debt to total asset (TDTA).

5. Kompleksitas Operasi Perusahaan

Kompleksitas operasi perusahaan merupakan salah satu karakteristik perusahaan yang dapat menambah suatu tantangan pada audit dan akuntansi (Givoly dan Palmon, 1982). Kompleksitas operasi perusahaan dalam penelitian ini ditentukan oleh ada atau tidaknya anak perusahaan. Variabel ini diukur dengan menggunakan dummy. Untuk perusahaan yang memiliki anak perusahaan diberi kode 1 sedangkan perusahaan yang tidak memiliki anak perusahaan diberi kode 0 .

6. Opini Auditor

Opini auditor afalah pendapat yang diberikan oleh auditor independen atas laporan keuangan yang disajikan oleh suatu perusahaan. Opini auditor dalam penelitian ini diukur dengan melihat jenis opini yang diberikan oleh auditor independen terhadap laporan keuangan perusahaan yang terdaftar di BEl. Alat ukur yang digunakan dalam variabel opini auditor adalah dengan menggunakan variabel dummy dengan kategori 1 apabila auditor memberikan opini unqualified opinion pada pelaporan keuangan auditan. Untuk opini selain unqualified opinion masuk pada kategori 0 .

Hipotesis pada penelitian ini akan diuji dengan menggunakan analisis tegresi berganda (multiple linear regression). Adapun model regresi berganda dalam penelitian ini adalah sebagai berikut:

$$
A D=\beta_{0}+\beta_{1} X_{1}+\beta_{2} X_{2}+\beta_{3} X_{3}+\beta_{4} X_{4}+\beta_{5} X_{5}+\varepsilon
$$

Keterangan :

$A D=$ Audit Delay

$\beta_{0}=$ Konstanta

$\beta_{1} X_{1}=$ Ukuran Perusahaan 
$\beta_{2} X_{2}=$ Profitabilitas

$\beta_{3} X_{3}=$ Solvabilitas

$\beta_{4} X_{4}=$ Kompleksitas Operasi Perusahaan

$\beta_{5} X_{5}=$ Opini auditor

$\varepsilon=$ error term, yaitu tingkat kesalahan dalam penelitian

Setelah dilakukan analisis dengan analisis regresi linier berganda maka dilakukan pengujian terhadap hipotesis. Metode pengujian hipotesis yang dilakukan adalah uji signifikansi simultan (uji $F$ ), uji koefisien determinasi $\left(R^{2}\right)$ dan uji signifikansi parsial (uji statistik T) (Ghozali, 2013).

\section{HASIL}

Analisis statistika deskriptif memberikan gambaran data mngenai karakteristik yang berpengaruh terhadap audit delay pada perusahaan LQ 45. Dalam penelitian ini, statistika deskriptif akan memberikan gambaran atau deskripsi suatu data yang dapat dilihat dari nilai minimum, nilai maksimum, nilai rata-rata (mean) dan standar deviasi. Berikut ini adalah hasil analisis deskriptif dengan menggunakan bantuan software SPSS 25 dari variabel-variabel yang diteliti. Berikut tabel 1 menyajikan statistika deskriptif data masing-masing variabel.

Tabel 1

Statistik Deskriptif

\begin{tabular}{lrrrrr}
\hline & N & \multicolumn{1}{c}{ Minimum } & Maximum & \multicolumn{1}{c}{ Mean } & \multicolumn{1}{c}{$\begin{array}{c}\text { Std. } \\
\text { Deviation }\end{array}$} \\
Audit Delay & 84 & 15 & 145 & 62,85 & 24,162 \\
Ukuran & 84 & 25,32522 & 34,88714 & 31,81693 & 1,62124 \\
$\begin{array}{l}\text { Perusahaan } \\
\text { ROA }\end{array}$ & 84 &,- 05722 &, 46660 &, 09565 &, 10010 \\
TDTA & 84 &, 14922 &, 86424 &, 52331 &, 22279 \\
Valid N & 84 & & & & \\
(listwise) & & & & & \\
\hline
\end{tabular}

Sumber: Output SPSS, 2020

Audit delay adalah lamanya waktu yang digunakan oleh auditor dalam melakukan proses audit terhadap laporan keuangan tahunan yang terhitung sejak tanggal tutup buku yaitu 31 Desember setiap tahunnya. Hasil analisis dengan menggunakan statistika deskriptif yang terdapat pada Tabel 1 menunjukkan bahwa rata-rata audit delay adalah 62,85 yang berarti proses audit laporan keuangan pada perusahaan LQ45 pada tahun 2017-2019 diselesaikan auditor independen rata-rata sebanyak 62,85 hari. Audit tercepat adalah 15 hari dan audit terlama adalah 145 hari. Informasi tersebut menunjukkan bahwa rata-rata proses audit perusahaan sampel masih dibawah 90 hari, yang merupakan batas yang ditetapkan oleh Bapepam dalam penyampaian laporan keuangan. Namun terlihat juga bahwa masih terdapat perusahaan yang menyampaikan laporan keuangan setelah batas tanggal waktu yang ditetapkan Bapepam.

Variabel ukuran perusahaan diukur dengan menggunakan total aset dari seluruh perusahaan sampel selama tahun 2017-2019 menunjukkan rata-rata sebesar 31,81693 yang berarti variasi data total aset perusahaan sampel cukup besar. Berdasarkan hasil analisis dengan 
statistik deskriptif nilai ukuran perusahaan minimum adalah 25,32522 atau sebesar Rp 99.679.570 yang dimiliki oleh PT. Jasa Marga (Persero) Tbk ditahun 2019. Nilai maksimum dari ukuran perusahaan ini sebesar 34,88714 atau sebesar Rp 1.416.758.840.000.000 yang dimiliki oleh PT. Bank Rakyat Indonesia (Persero) Tbk di tahun 2019.

Variabel profitabilitas merupakan salah satu rasio yang membandingkan antara laba bersih dengan total aktiva. Dalam penelitian ini, profitabilitas menunjukkan rata-rata sebesar 0,09565. Rasio profitabilitas terendah adalah $-0,5722$, nilai negatif berarti perusahaan mengalami kerugian dibandingkan dengan total aset perusahaan. Sedangkan rasio profitabilitas tertinggi adalah sebesar 0,46660 .

Variabel solvabilitas merupakan salah satu rasio yang membandingkan nilai total utang/liabilitas dengan total aset perusahaan. Dalam penelitian ini, solvabilitas menunjukkan rata-rata sebesar 0,52331. Artinya proporsi hutang pada perusahaan yang menjadi sampel memiliki rata-rata sebesar $53,31 \%$ dari seluruh aset yang dimiliki perusahaan, sedangkan sisanya perusahaan memanfaatkan modal/ekuitas yang dimiliki. Hal ini menunjukkan perusahaan LQ 45 masih cukup wajar dalam mengandalkan utang. Tingkat solvabilitas terendah adalah 0,14922 yaitu PT Indocement Tunggal Prakasa (Persero) Tbk di tahun 2017 sedangkan tingkat solvabilitas tertinggi adalah 0,86424 yaitu PT Bank Tabungan Negara (Persero) Tbk di tahun 2019.

Hasil pengujian statistik deskriptif variabel kompleksitas ukuran perusahaan dan opini auditor dalam penelitian ini dihitung menggunakan skala dummy sehingga deskripsinya dilakukan secara terpisah. Berikut ini adalah hasil uji statistik deskriptif variabel kompleksitas ukuran perusahaan yang dapat dilihat pada tabel 2 dan variabel opini auditor pada tabel 3.

\begin{tabular}{|c|c|c|c|c|c|}
\hline & \multicolumn{5}{|c|}{$\begin{array}{c}\text { Tabel } 2 \\
\text { Statistik Deskriptif }\end{array}$} \\
\hline & & Frequency & Percent & Valid Percent & $\begin{array}{l}\text { Cumulative } \\
\text { Percent }\end{array}$ \\
\hline \multirow[t]{3}{*}{ Valid } & $\begin{array}{l}\text { Perusahaan yang } \\
\text { memiliki anak perusahaan }\end{array}$ & 75 & 89,3 & 89,3 & 89,3 \\
\hline & $\begin{array}{l}\text { Perusahaan yang tidak } \\
\text { memiliki anak perusahaan }\end{array}$ & 9 & 10,7 & 10,7 & 100,0 \\
\hline & Total & 84 & 100,0 & 100,0 & \\
\hline
\end{tabular}

Sumber: Output SPPS, 2020

Hasil pengujian statistik deskriptif pada tabel 2 menunjukkan bahwa perusahaan yang memiliki anak perusahaan sebanyak 75 perusahaan yaitu sebesar $89,3 \%$ sedangkan perusahaan yang tidak memiliki anak perusahaan sebanyak 9 perusahaan yaitu sebesar $10,7 \%$. 
Tabel 3

Statistika Deskriptif

\begin{tabular}{|c|c|c|c|c|c|}
\hline & & Frequency & Percent & Valid Percent & $\begin{array}{l}\text { Cumulative } \\
\text { Percent }\end{array}$ \\
\hline \multirow[t]{3}{*}{ Valid } & $\begin{array}{l}\text { Non Unqualified } \\
\text { Opinion }\end{array}$ & 30 & 35,7 & 35,7 & 35,7 \\
\hline & Unqualified Opinion & 54 & 64,3 & 64,3 & 100,0 \\
\hline & Total & 84 & 100,0 & 100,0 & \\
\hline
\end{tabular}

Sumber: Output SPSS, 2020

Hasil pengujian statistika deskriptif pada tabel 3 menunjukkan bahwa perusahaan yang mendapatkan opini selain Unqualified Opinion adalah sebanyak 54 perusahaan yaitu sebesar $64,3 \%$ sedangkan yang mendapatkan non Unqualified Opinion adalah sebanyak 30 perusahaan yaitu sebesar 35,7\%.

Berdasarkan hasil uji asumsi klasik, penelitian ini tidak mengalami penyimpangan asumsi klasik yang ditandai dengan data terdistribusi secara normal, tidak terjadi multikolinearitas, tidak ada autokorelasi dan tidak terjadi heteroskedastisitas. Data terdistribusi secara normal dibuktikan dengan jumlah data yang diuji lebih dari 30. Bukti data lolos uji asumsi klasik juga ditunjukkan oleh nilai variance inflation factor (VIF) dibawah 10 atau nilai tolerance berada diatas 0,1 . Pada uji autokorelasi menggunakan run test dapat dideteksi dengan melihat Asymp. Sig. (2-tailed) sebesar 0,661 yang lebih besar dari 5\% atau 0,05 yang berarti tidak terjadi autokorelasi. Selanjutnya hasil uji heterokedastisitas dengan menggunakan scatterplot, terliat bahwa titik-titik pada grafik scatterplot tidak membentuk pola tertentu yang teratur. Terbukti bahwa asumsi barian dalam residual adalah homogen atau tidak terjadi heterokedastisitas.

Karena data penelitian sudah memenuhi seluruh asumsi klasik, maka selanjutnya dapat dilakukan analisis regresi berganda dan pengujian hipotesis. Pengujian hipotesis dilakukan dengan uji koefisien determinasi (Adjusted $R^{2}$ ), uji koefisien simultan (Uji F) dan Uji Signifikansi Parsial (Uji T). Uji koefisien determinasi $\left(R^{2}\right)$ menunjukkan nilai Adjusted $R$ sebesar 0,365 yang artinya kemampuan variabel independen dalam menjelaskan varian variabel independennya hanya sebesar 36,5\% sedangkan sisanya sebesar 63,5\% dijelaskan oleh variabel lain yang tidak terdapat dalam penelitian ini. Uji statistik $F$ menunjukkan nilai $F$ sebesar 10,542 dengan probabilitas 0,000 . Nilai probabilty value (sig) lebih kecil dari 0,05 yang menunjukkan bahwa model regresi layak untuk diteliti karena memenuhi goodnes of Fit. Hasil analisis regresi dengan menggunakan metode analisis regresi linier berganda dan pengujian hipotesis disajikan pada tabel 4 sebagai berikut:

Tabel 4

Hasil Uji Signifikansi Parsial (Uji T)

\begin{tabular}{crrrrr}
\hline \multirow{2}{*}{ Model } & \multicolumn{6}{c}{ Unstandardized } & \multicolumn{2}{c}{$\begin{array}{c}\text { Standardized } \\
\text { Coefficiens }\end{array}$} & \multicolumn{2}{c}{ Coefficients } & \multirow{2}{*}{ Sig. } \\
\cline { 2 - 4 } & \multicolumn{1}{c}{ B } & Std. Error & Beta & & \\
\hline (Constant) & 224,190 & 49,816 & & 4,500 &, 000 \\
Ukuran & $-4,316$ & 1,602 &,- 290 & $-2,694$ &, 009 \\
Perusahaan & & & & & \\
ROA & $-49,535$ & 24,692 &,- 205 & $-2,006$ &, 048 \\
TDTA & $-49,342$ & 13,168 &,- 455 & $-3,747$ &, 000 \\
Kompleksitas & 3,339 & 7,963 & 0,43 &, 419 &, 676
\end{tabular}


Opini Auditor

$$
5,521
$$

4,804

, 110

1,149

,254

a. Dependent Variable: Audit Delay

Sumber: output SPSS, 2020

Berdasarkan hasil uji statistik $\mathrm{t}$ pada tabel 4, maka dapat dirumuskan persamaan regresi linier berganda sebagai berikut:

Audit Delay $=224,190-4,316$ Ukuran Perusahaan - 49,535 Profitabilitas 49,342 Solvabilitas $+3,339$ Kompleksitas Operasi Perusahaan + 5,521 Opini Auditor + e

Hasil pengujian hipotesis pertama mendapatkan bahwa ukuran perusahaan mempunyai pengaruh yang signifikan terhadap audit delay. Hal ini dapat dilihat dari nilai signifikansi t pada tabel 4 yaitu ukuran perusahaan menunjukkan nilai 0,009 lebih kecil dari 0,05. Hal ini berarti bahwa aset yang dimiliki perusahaan mempunyai pengaruh signifikan terhadap audit delay. Hal ini dikarenakan semakin besar perusahaan, maka perushaan itu memiliki pengendalian internal yang baik sehingga dapat mengurangi tingkat kesalahan dalam penyajian laporan keuangan sehingga memudahkan auditor dalam melakukan pengauditan atas laporan keuangan.

Hasil pengujian hipotesis kedua menunjukkan bahwa profitabilitas memiliki pengaruh yang signifikan terhadap audit delay. Hal ini dapat dilihat dari nilai signifikansi t pada tabel 4 yaitu profitabilitas menunjukkan nilai 0,048 kurang dari 0,05 . Semakin tinggi tingkat profitabilitas suatu perusahaan maka ada kecenderungan semakin singkatnya suatu audit delay. Sebaliknya, jika semakin kecil tingkat profitabilitas maka akan cenderung semakin lama suatu audit delay perusahaan. Hal ini dikarenakan, perusahaan dengan tingkat profitabilitas yang tinggi cenderung mempercepat proses auditingnya, agar dapat mempublikasikan hasil kinerja mereka yang dianggap baik sehingga dapat meningkatkan citra baik bagi perusahaan.

Hasil pengujian hipotesis ketiga menunjukkan bahwa solvabilitas memiliki pengaruh yang signifikan terhadap audit delay. Hal ini dapat dilihat dari nilai signifikansi t pada tabel 4 yaitu solvabilitas menunjukkan nilai 0,000 kurang dari 0,05 . Nurrahman Apriyana (2017) mengatakan bahwa besar kecilnya utang yang dimiliki perusahaan akan menyebabkan pemeriksaan dan pelaporan terhadap pemeriksaan utang perusahaan semakin lama sehingga dapat memperlambat proses pelaporan audit oleh auditor. Perusahaan yang masih memiliki proporsi total utang yang tinggi dibandingkan dengan total aset akan meningkatkan kecenderungan kerugian. Hal ini akan membuat auditor berhati-hati terhadap laporan keuangan yang akan diaudit karena menyangkut kelangsungan hidup perusahaan.

Hasil pengujian hipotesis keempat menunjukkan bahwa kompleksitas operasi perusahaan tidak mempunyai pengaruh signifikan terhadap audit delay. Hal ini dapat dilihat dari nilai signifikansi t pada tabel 4 yaitu kompleksitas operasi perusahaan menunjukkan nilai 0,676 lebih dari 0,05. Tingkat kompleksitas operasi sebuah perusahaan yang bergantung pada jumlah dan lokasi uni operasinya (cabang) serta diversifikasi jalur produk dan pasarnya cenderung mempengaruhi waktu yang dibutuhkan oleh auditor untuk menyelesaiakan pekerjaan auditnya. Hal ini yang membuat lingkup audit yang akan dilakukan oleh auditor semakin luas, sehingga berdampak pada waktu yang dibutuhkan oleh auditor dalam menyelesaikan tugas auditnya.

Hasil pengujian hipotesis kelima menunjukkan bahwa opini auditor tidak berpengaruh signifikan terhadap audit delay. Hal ini dapat dilihat dari nilai 
signifikansi t pada tabel 4 yaitu opini auditor menunjukkan nilai 0,254 yang artinya lebih dari 0,05 . Pendapat yang dikeluarkan oleh auditor terhadap laporan keuangan yang dimiliki oleh suatu perusahaan ternyata tidak mempunyai pengaruh yang signifikan terhadap audit delay. Hal ini terjadi karena jenis pendapat auditor merupakan goodnews atau badnews atas kinerja manjerial perusahaan dalam setahun bukan merupakan faktor penentu dalam ketepatan waktu pelaporan audit. Kebijakan untuk mengatur waktu penyelesaian audit merupakan kesepakatan antara pihak auditor dan perusahaan klien (Arif Wicaksono, 2009).

\section{KESIMPULAN}

Penelitian ini memiliki tujuan untuk menguji secara empiris pengaruh dari ukuran perusahaan, profitabilitas, solvabilitas, kompleksitas operasi perusahaan dan opini auditor terhadap audit delay. Dari lima faktor yang diteliti tersebut terbukti bahwa ukuran perusahaan, profitabilitas dan solvabilitas berpengaruh signifikan terhadap audit delay. Sedangkan variabel kompleksitas operasi perusahaan dan opini auditor tidak berpengaruh signifikan terhadap audit delay.

Penelitian ini memiliki keterbatasan. Pertama, sampel yang digunakan dalam penelitian ini hanya terkumpul sebanyak 28 perusahaan dalam satu periode penelitian. Hal ini disebabkan karena perusahaan yang secara konsisten masuk dalam indeks LQ 45 selama tiga tahun berturut-turut sejumlah 28 perusahaan. Kedua, dari hasil penelitian terlihat bahwa kemampuan dari lima variabel independen yang digunakan pada penelitian ini hanya dapat menjelaskan variabel dependen sebesar $36,5 \%$. Hal ini berarti masih terdapat $63,5 \%$ variabel audit delay yang dapat dijelaskan oleh variabel lain yang tidak dimasukkan dalam model peneltiian ini.

Berdasarkan keterbatasan penelitian, maka peneliti memberikan beberapa saran yang dapat dipertimbangkan pada penelitian selanjutnya. Pertama, bagi peneliti selanjutnya diharapkan untuk menggunakan sampel perusahaan yang lebih luas karena pada penelitian ini hanya berfokus pada perusahaan yang tergolong LQ 45 di Bursa Efek Indonesia. Kedua, menambah variabel lain yang mungkin dapat berpengaruh terhadap audit delay. Hal ini dikarenakan nilai dari koefisien determinasi yang kecil sehingga masih banyak faktor lain yang dapat mempengaruhi audit delay selain variabel-variabel yang telah digunakan dalam penelitian ini. Ketiga, menambah periode waktu atau periode penelitian. Hal ini dilakukan untuk dapat memberikan hasil yang akurat.

\section{DAFTAR PUSTAKA}

Abadi, Yogi Setya. (2017). Pengaruh Profitabilitas, Ukuran Perusahaan, Kompleksitas Operasi Perusahaan dan Reputasi KAP Terhadap Audit Report Lag. Skripsi, Universitas Muhammadiyah Surakarta.

Apriliane, Malinda Dwi. (2015). Analisis Faktor-Faktor yang Mempengaruhi Audit Delay pada Perusahaan Pertambangan yang Terdaftar di Bursa Efek Indonesia. Skripsi, Universitas Negeri Yogyakarta. 
Apriyana, Nurahman. (2017). Pengaruh Profitabilitas, Solvabilitas, Ukuran Perusahaan, dan Ukuran KAP Terhadap Audit Delay pada Perusahaan Properti dan Real Estate yang Terdaftar Di Bursa Efek Indonesia Periode 2013-2015. Jurnal Nominal, 6(2): 108-124.

Bursa Efek Indonesia (BEI). (2011). Peraturan No. III-F Surat Keputusan Direksi PT Bursa Efek Indonesia No. Kep-00085/BEl/10-2011 tentang Sanksi. 19 Oktober 2011. Jakarta.

Gani, Petrus. (2019). Pengaruh Ukuran Perusahaan, Solvabilitas dan Profitabilitas terhadap Audit Delay. Jurnal IImiah Core IT e-ISSN: 2548-3528 p-ISSN: 2339-1766.

Ghozali, Imam. (2013). Aplikasi Analisis Multivariate dengan Program IBM SPSS 21. Update PLS Regresi. Semarang: Badan Penerbit Universitas Diponegoro.

Givoly. D., \& Palmon. D. (1982). Timeliness of Annual Earnings Announcements: Some Empirical Evidence. The Accounting Review, 7(3).

Johson, E. Laurence. (1998). Futher Evidence On The Determinants of Local Goverment Audit Delay. Journal of Public Budgeting, Accounting \& Financial Management, 10(3): 375 - 397.

Kieso, Donald E. Jerry J.Weygandt, Paul D. Kimmel. (2014). Accounting Principles Pengantar Akuntansi Edisi 7 Jilid 1. Jakarta: Salemba 4.

Lestari, S.Y., dan M. Nuryatno. (2018). Faktor Yang Mempengaruhi Audit Delay dan Dampaknya Terhadap Abnormal Return Perusahaan Di Bursa Efek Indonesia. Jurnal Analisa Akuntansi dan Perpajakan, 1(2): 63.

Peraturan Bapepam dan LK X.K.2 (Salinan Keputusan Ketua Badan Pengawas Pasar Modal dan Lembaga Keuangan Nomor: KEP346/BL/2011) tentang Penyampaian Laporan Tahunan Emiten atau Perusahaan Publik.

Sari, Belani Yudita. (2015). Analisis Faktor-Faktor yang Mempengaruhi Audit Delay pada Perusahaan Manufaktur yang Terdaftar di Bursa Efek Indonesia. Skripsi, Sekolah Tinggi Ilmu Ekonomi Yogyakarta.

Undang-Undang No. 8 Tahun 1995 Tentang Pasar Modal

Wicaksono, A. (2009). Analisis Faktor-Faktor yang Berpengaruh terhadap Audit Delay di Indonesia. Skripsi, Universitas Pembangunan Nasional "Veteran" Yogyakarta.

Widosari, Shinta Altia. (2012). Analisis Faktor-Faktor yang Berpengaruh Terhadap Audit Delay pada Perusahaan Manufaktur di Bursa Efek Indonesia. Skripsi, Universitas Diponegoro Semarang.

Yuliyanti, Ani. (2011). Faktor-Faktor yang Berpengaruh Terhadap Audit Delay. Skripsi, Universitas Negeri Yogyakarta. 